After three years in the mill the students obtain a degree, gained under conditions calculated to minimise what should be one of the most important features in any university training: the learning to think and overcome difficulties for oneself. There is thus a growing annual output of graduates of both sexes who find, of ten too late, that their qualifications only fit them for one career: that of swelling the ranks of the already overcrowded and underpaid teaching profession. The production of a certain number of schoolmasters is a necessary element in the educational system of every country, but the question is: should this or the advancement of higher learning be the main function of a university endowed with public funds?

Many provincial colleges plead poverty as an excuse for overburdening their staffs with pedagogic and tutorial work. But these colleges are not too poor to vie with each other in the award of small scholarships, many of which go to pass students of no great ability. And experience, both in America and in this country, has shown that if only such objects as endowment of research are prominently brought before public notice, support will not be found wanting.

In conclusion, the directions where reform is most needed include the following :-

(1) Discontinuance of matriculation preparation-work which naturally belongs to the province of schools and crammers.

(2) Recognition of research work rather than tutorial instruction of pass candidates as the main duty of a professor outside his class-room.

(3) Reduction of the hours of class work, both of teachers and students.

(4) Revision of the now precarious conditions under which provincial appointments are tenable.

(5) Attraction of public attention to the importance of providing facilities for professorial research.

(6) The appointment of more and better paid assistantlecturers and demonstrators.

(7) A more judicious expenditure of scholarship money, which should be restricted to honours students.

If the new university systems of this country are not, in the course of a few years, to take a subordinate position, and their degrees to sink into disrepute, if, in short, we are not to be left in the lurch by our foreign rivals, it becomes the duty of all who are responsible for the management of our provincial colleges and universities to have their attention aroused to a state of affairs which too often results in their professors being sweated and their students crammed.

\section{GOVERNMENT GRANT IN AID OF ANTARCTIC EXPLORATION.}

$\mathrm{THE}$ following letter, referring to a Parliamentary grant in aid of Antarctic exploration, has been received by Lord Lister from H.M. Treasury, and sent to us by the Secretaries of the Royal Society :--

Trexsury Chambers, July 3, 1899 .

My LORD,-I am directed by the Lords Commissioners of Her Majesty's Treasury to inform you that the First Lord has laid before the Board the memorial signed by your Lordship as President of the Royal Society, by the President of the Royal Geographical Society, and by other distinguished representatives of various branches of science, by which memorial application is made for a Government grant in aid of the expedition now being organised by the Royal Society and the Royal Geographical Society for the exploration of the Antarctic regions. This application has received the careful consideration of Her Majesty's Government, and I am directed to inform you that they are prepared to ask Parliament for grants amounting, in all, to $45,000 l$. NO. I 550 , VOL. 60] towards the expenses of the proposed expedition, provided you are able to assure them that not less than an equal amount will be forthcoming from other sources, so as to enable the scheme to be efficiently carried out.

In making this announcement, I am to call attention to the latter part of the speech of the First Lord to the deputation which waited on him on this subject, as indicating that Her Majesty's Government must not be regarded, in making this promise, as inaugurating a new era of more extensive grants than formerly from the Exchequer in aid of scientific enterprises. Rather, it is to be understood that the very exceptional importance of the present scheme, so strongly represented by the deputation, is being recognised by the promise of a special grant.

At the present time, it is only necessary to add that the applications to Parliament for instalments of the grant will be spread over four years, of which 1900-1901 will be the first.

I am to ask you to be so good as to communicate this decision to the other signatories of the memorial. I am, My Lord, (Signed) FrancIS MOWATT.

LORD LISTER, President of the Royal Society, Burlington House.

\section{NOTES}

THE Paris Academy of Sciences has been authorised to increase its number of national and foreign Correspondants from 100 to I 16.

THE British Medical Journal announces that Sir John Burdon Sanderson, Bart., and Prof. Michael Foster, K.C. B., will be entertained at dinner by British physiologists on July 20 , to congratulate them on the honours recently conferred on them by the Queen. The dinner will take place at the "Star and Garter," Richmond.

THE Volta Centenary Exhibition at Como, described in NATURE of June 22, has been completely destroyed by a fire, attributed to the fusing of some electric wires. Practically all the precious Volta relics were lost in the flames, notwithstanding the precaution taken to preserve the objects by placing them in a receptacle of solid masonry. The only things saved were a sword of honour presented by Napoleon the First to Volta, a picture by Bertini of Volta explaining his battery to Napoleon, a cast of the great electrician's skull, his watch, and a few personal relics. Volta's books and manuscripts, some of which were recently bought by the Italian Governmer for 100,000 lire, his collection of batteries, the only authentic portrait of Volta, his will, \&c., were all destroyed. In spite of the destruction of the Exhibition, the committee has decided that the fêtes in honour of Volta shall be continued. The International Congress of Electricians will be held as previously arranged.

Prof. Ewar'r exhibited a number of his zebra hybrids, their dams, sire, and half-brothers and sisters, at the great Agricultural Show recently held in Edinburgh. The authorities were little prepared for the interest taken in the exhibit, with the result that many thousands either falled to see anything of the hybrids, or had but a passing glance. The Prince of Wales, accompanied by a deputation of the Royal Agricultural Society of England, made a special inspection of the mixed family. From a contemporary we learn the Prince was so greatly interested that he requested Prof. Ewart to make a similar exhibition next summer at the Royal Agricultural Societies' Show at York. Should breeders give up empirical in favour of scientific methods, not a 